\title{
Growth Responses of Apical Shoots Rootstock Rubber with Retardants Application and Effect on Grafting Success
}

\author{
Sarman Sarman ${ }^{1 *}$, Zainal Ridho Djafar ${ }^{2}$, Yakup Parto ${ }^{2}$, and \\ Heru Suryaningtyas ${ }^{3}$ \\ ${ }^{1}$ School of Agroecotechnology, Faculty of Agriculture, Jambi University \\ ${ }^{2}$ School of Agroecotechnology, Faculty of Agriculture, Sriwijaya University \\ ${ }^{3}$ Sembawa Research Centre, Rubber Research Centre, South Sumatera, Indonesia \\ * Corresponding author.Email: sarman_pertanian@unja.ac.id
}

\begin{abstract}
This research aimed to study the effect of retardants concentration on the inhibition of apical shoots of rubber rootstock and analyze the relationship between the apical bud dormancy and grafting success relating to the influence of retardants. The study was conducted in the Teaching and Research Farm land, Faculty of Agriculture, Jambi University, Mendalo Darat Campus, Jambi Luar Kota District, Muaro Jambi Regency, on $35 \mathrm{~m}$ above sea level. Carbohydrate content analysis was carried out in the Basic and Integrated Laboratory of Jambi University. The research method used is Randomized Block Design with one factor this is retardan and three replications. The applied treatments are: $r_{o}=$ no treatment; $r_{1}=$ paclobutrazol $500 \mathrm{ppm} ; \mathrm{r}_{2}=$ paclobutrazol $750 \mathrm{ppm} ; \mathrm{r}_{3}=$ paclobutrazol $1.000 \mathrm{ppm} ; \mathrm{r}_{4}=$ paclobutrazol $1.250 \mathrm{ppm} ; \mathrm{r}_{5}=$ paclobutrazol $1.500 \mathrm{ppm} ; \mathrm{r}_{6}=$ cycocel $1.000 \mathrm{ppm} ; \mathrm{c}_{7}=$ cycocel $2.000 \mathrm{ppm} ; \mathrm{c}_{8}=$ cycocel $3.000 \mathrm{ppm}$. Overall, there are 9 treatments and 27 research unit. There are 12 plants on each research. The results showed that the application of paclobutrazol at concentrations of $1.500 \mathrm{ppm}$ inhibits apical bud emergence on rubber seeds for 9 days and cycocel at a concentration of $3.000 \mathrm{ppm}$ for 10 days. Inhibition of apical buds with paclobutrazol application to a concentration of $1,000 \mathrm{ppm}$ can maintain the appearance of apical buds without inhibiting the growth and success of the grafting. Cycocel can slow the buds appear, without affecting the success of grafting.
\end{abstract}

Keywords: apical shoots, paclobutrazol, cycocel, grafting

\section{INTRODUCTION}

The attempt to increase rubber plant production can be performed through new area development program, the replanting of old rubber plants, and intensification. All of these programs would have effects on planting material demand. Material such as seedling is an initial principal for plant growth. Therefore, the differences in physical and biochemical aspect of planting material, which are widely defined as quality, can have an impact on initial plant growth.

Nowadays, the currently suggested application of rubber planting material is the one obtained from multiplication by grafting. It is conducted by mixing original rootstock with scions from entres and both are from suggested clones' recommendation.

The conclusion from research findings and practitioner's experience show that growth condition of rootstock is one of critical factors of successful grafting. The ideal condition for grafting is when the leaves on the highest canopy are in old leaf stadia, because if the leaves are too young, it will be difficult to exfoliated [2];[11];[19]. Therefore, according to [1], the most ideal condition for grafting is when the apical shoot is in dormant condition.

To maintain dormant stadia of rubber plant seedling is a critical issue because of the occurrence of periodical growth period of rubber plant apical shoot which is, according to [12], caused by growth rhythm of shoot and canopy leaves controlled by internal factors. This cycle keeps repeated in a fairly long-time space from dormant stadia- flush - old leaves stadia - dormant condition, within $30-40$ days. Reported from his research findings that the time required from dormant condition to the occurrence of new shoot is between 20 - 21 days [17]. 
Based on the explanation above, an attempt to expand dormant period of apical shoot is needed to maintain stadia condition of mature leaves on rubber plant's rootstock so that such this required ideal condition can survive longer and the success of grafting remains high. However, this attempt is expected not to suppress plant's growth and development. Therefore, an innovation is needed to tackle this problem, which is by maintaining this seedling's dormant stadia by applying retardant. This growth retardation mechanism can expand dormant time of rootstock of rubber plant seedling shoot.

Application of retardant to suppress plant growth, especially on shoot, has not been widely reported. However, there have been so many applications for controlling vegetative growth and production as well as for increasing plant tolerance against drought threat. Some examples of widely applied retardants are paclobutrazol to retard height on cengkeh to make it easy to harvest [15] and cycocel to suppress vegetative growth of manggis to increase root growth [8].

To discover method to expand dormant stadia of rubber plant seedling rootstock shoot, the information about growth retardant needs to be studied. The objective of this study is to analyses the effect of retardant on shoot retardation, seedling growth and the success of grafting.

\section{MATERIALS AND METHOD}

This experiment was conducted at Teaching and Research Farm area, Faculty of Agriculture, Jambi University, Mendalo Darat Campus, Jambi Luar Kota District, Muaro Jambi Regency. Planting materials used are rootstock rubber plant seedlings in polybag with two canopy leaves and entres. The clone used for rootstock an entres is obtained from PB260 clone.

The research method used is Randomized Block Design with one factor this is retardan and three replications. The applied treatments are: ro $=$ no treatment; $\mathrm{r} 1=$ paclobutrazol 500 ppm; $\mathrm{r} 2=$ paclobutrazol $750 \mathrm{ppm}$; 3 = paclobutrazol $1.000 \mathrm{ppm} ; \mathrm{r} 4$ $=$ paclobutrazol $1.250 \mathrm{ppm} ; \mathrm{r} 5=$ paclobutrazol 1.500 ppm; r6 = cycocel 1.000 ppm; c7 = cycocel 2.000 ppm; c8 = cycocel $3.000 \mathrm{ppm}$. Overall, there are 9 treatments and 27 research unit. There are 12 plants on each research.

The planting materials for rubber plant seedling rootstock were obtained from seeds which were seedling on sand medium. The germinate seeds on needle stadium were then moved to polybags. The planting medium was mixture of top soil and organic fertilizer with ratio 2:1. The size of polybag was $25 \mathrm{~cm}$ x $50 \mathrm{~cm}$ with medium weight $15 \mathrm{~kg}$ per polybag. NPK Fertilizer (16-16-16) with dose 2 gr per polybag was given to rubber seedlings at the first, second, and third month until the final time of the research with total fertilizer dose given was 5 gr per polybag. To cure corynespora disease found during research, the plants were treated by applying Dithane M$45^{\mathrm{TM}}$ and for controlling weeds, they were treated by applying Noxone $397 \mathrm{SL}^{\mathrm{TM}}$. The tools used were grafting knife, digital vernier calipers, a ruler, water pump, and hand sprayer.

Retardants such as Paclobutrazol and Cycocel were applied when the plants were 6 months old (the second phase of canopy leaves), and the apical shoot was in dormant condition. The treatment was given by spraying $15 \mathrm{ml}$ retardants per seedling on plant's growth point. The spraying was performed four times with one week interval from 6 to 7 o'clock in the morning.

The observed variables encompassed growth components such as initial shoot growth, shoot length, total leave area, stem circlet, bark thickness, shoot dry weight, and other variables related to grafting success such as the ease of bark ripping and stem bark carbohydrate content. This analysis was conducted by Phenol Sulphate method introduced by [20], and the sample used was stem bark around grafting window. The analysis was conducted at Basic and Integrated Laboratory Jambi University.

\section{RESULTS AND DISCUSSION}

The result of statistical analysis of observation data is shown in Table 1. It is shown that application of paclobutrazol and cycocel with various concentrations has an effect on the parameter such as shoot's initial growth, shoot's length, and stem circle. However, the effect is considered low on the other parameters.

\subsection{Effect of retardant on intial shoot growth}

Application of paclobutrazol and cycocel to retard the emergence of apical shoot on rubber seedling's rootstock is obviously effective. Table 2 shown that the treatment with highly concentrated retardant $(1.500 \mathrm{ppm})$ effectively retards the apical shoot to grow, compared to the one with lower concentration. The same effect can be seen on the treatment with highly concentrated cycocel $(3.000 \mathrm{ppm})$, but the retardation effect is stronger. It is shown by the difference in the emergence day of the apical shoot where the emergence after cycocel treatment is slighty lower from the paclobutrazol one ( 9 days and 10 days respectively).

The retardation's response above indicates that the application of paclobutrazol and cycocel can suppress the extension growth of meristem cell on the shoot. Explained that apical shoot meristem is the mass generated from cells that membelah at the edge of the shoot. A large portion of shoot extension is caused by extension of internodus cells under the edge the shoot [6]. 
Table 1. Results of analysis of variance retardants influence on the observed variables.

\begin{tabular}{cllc}
\hline No. & \multicolumn{1}{c}{ Variabel } & F $\mathrm{F}_{\text {calc }}$ & c.v. $(\%)$ \\
\hline 1 & Shoot growth (day) & $9,26^{* *}$ & 10,52 \\
2 & Shoot length (cm) & $2,92^{*}$ & 10,62 \\
3 & Total leave area (cm $\left.{ }^{2}\right)$ & $0,34 \mathrm{~ns}$ & 11,82 \\
4 & Stem Circlet (cm) & $2,86^{*}$ & 10,81 \\
5 & Bark thickness (mm) & $1,01 \mathrm{~ns}$ & 17,70 \\
6 & Shoot dry weight & $1,37 \mathrm{~ns}$ & 13,07 \\
7 & Bark ripping (\%) & $0,09 \mathrm{~ns}$ & 12,31 \\
8 & Carbohidrat content (\%) & $0,83 \mathrm{~ns}$ & 13,76 \\
9 & Grafting succes (\%) & $0,16 \mathrm{~ns}$ & 11,13 \\
\hline
\end{tabular}

*** significant in the 0,05 and 0,01 level, $\mathrm{ns}=$ non significant

[7] claimed that the cell extended growth is stimulated by gibberellin, a type of growth regulator substance, therefore if this gibberellin biosynthesis is suppressed, the apical shoot growth will stop.

It is estimated that the difference in the effect of paclobutrazol and cycocel on the emergence of shoot happened due to the retardation mechanism performed by these two retardants at different gibberellin biosynthesis step. Paclobutrazol retards, oxidation reaction between kauren and kaurenoat [16]; [7], while cycocel retards the formation of cyclist ring from geranylgeranyl pyrofosfat
Cycocel manages to retard division and elongation of cell which cause the decrease in vegetative growth. According to [5], the retardation of plant's height due to the application of cycocel probably happened because the shortening of internode through division and a decline in the number of cell. Explained that cycocel is inhibitor anti- gibberellin and dwarfing agents. He also claimed that spraying of cyocel to the plant will induce gibberellin deficiency and eventually reduce the growth through blocking and conversion from geranyl pyrophosphate ke copanyl pyrophosphate which is the beginning of gibberellin synthesis [13].

Table 2. Retardan influence on Shoot growth, Shoot length, Total leave area Stem Circlet, Bark thickness dan Shoot dry weight. 王

\begin{tabular}{|c|c|c|c|c|c|c|}
\hline \multirow{2}{*}{$\begin{array}{l}\text { Retardant } \\
\text { (ppm) }\end{array}$} & \multicolumn{6}{|c|}{ Variabel } \\
\hline & $\begin{array}{c}\text { Shoot growth } \\
\text { (HSP) }\end{array}$ & $\begin{array}{l}\text { Shoot length } \\
(\mathrm{cm})\end{array}$ & $\begin{array}{l}\text { Total leave } \\
\text { area }\left(\mathrm{cm}^{2}\right)\end{array}$ & $\begin{array}{c}\text { Stem } \\
\text { Circlet } \\
(\mathrm{cm})\end{array}$ & $\begin{array}{c}\text { Bark } \\
\text { thickness } \\
(\mathrm{mm})\end{array}$ & $\begin{array}{l}\text { Shoot dry } \\
\text { weight } \\
\text { (g) }\end{array}$ \\
\hline 0 & $20,40 \mathrm{ab}$ & $35,73 \mathrm{c}$ & 1601,31 & $5,61 \mathrm{c}$ & 2,06 & 636,56 \\
\hline \multicolumn{7}{|l|}{ Paclobutrazol } \\
\hline 500 & $18,27 \mathrm{a}$ & $33,93 \mathrm{c}$ & 1588,67 & $5,35 \mathrm{c}$ & 1,77 & 567,74 \\
\hline 750 & $22,47 \mathrm{~b}$ & $32,13 \mathrm{bc}$ & 1582,19 & $5,02 \mathrm{bc}$ & 1,61 & 561,63 \\
\hline 1.000 & $26,20 \mathrm{c}$ & $28,17 \mathrm{ab}$ & 1581,78 & $4,36 \mathrm{ab}$ & 1,55 & 547,30 \\
\hline 1.250 & $29,07 \mathrm{~cd}$ & $27,40 \mathrm{ab}$ & 1479,70 & $4,24 \mathrm{a}$ & 1,58 & 500,55 \\
\hline 1.500 & $29,55 \mathrm{~cd}$ & $27,10 \mathrm{a}$ & 1468,79 & $4,16 \mathrm{a}$ & 1,54 & 488,27 \\
\hline \multicolumn{7}{|l|}{ Cycocel } \\
\hline 1.000 & $19,73 \mathrm{ab}$ & $33,17 \mathrm{c}$ & 1576,42 & $5,22 \mathrm{c}$ & 1,67 & 547,49 \\
\hline 2.000 & $26,00 \mathrm{c}$ & $31,60 \mathrm{abc}$ & 1526,22 & $5,04 \mathrm{bc}$ & 1,86 & 513,94 \\
\hline 3.000 & $30,20 \mathrm{~d}$ & $27,83 \mathrm{ab}$ & 1437,99 & $4,98 \mathrm{bc}$ & 1,59 & 489,70 \\
\hline
\end{tabular}

The numbers followed the same letter in the same column not significant at $5 \%$ level DMRT

to ent-kauren. This explanation, it can be assumed that the earlier the gibberellin biosynthesis is retarded, the slower the shoot growth is.

Research findings of [10] explained that reduced cell growth happened as a result of the application of paclobutrazol. Application of paclobutrazol on soil managed to suppress the shoot's age extension of Eucalyptus globulusup to $50-60 \%$ and survive $2-3$ years after the treatment.

\subsection{Effect of retardant on the shoot's length.}

The shoot length observation result in Table 2 shows that the application of paclobutrazol and cycocel has a huge effect on apical shoot's extension of rubber seedling rootstock. Data in Table 2 illustrates that the average length of rubber seedlings treated by the application of paclobutrazol and cycocel is lower than the ones not. The research finding shows that an increase in the 
concentration of paclobutrazol and cycocel up to 1500 and $3000 \mathrm{ppm}$ respectively successfully reduce average length of rubber seedlings shoot at 24.16 and $22.11 \%$ respectively compared to the ones not.

This research finding proves the occurrence of retardation on plant's vegetative growth. A research by [15] on clove explained that the average length of clove plant apical shoot's internode after the application of paclobutrazol is lower than the ones without treatment. When the paclobutrazol's applied concentration is 25 ppm, the average seedling's height is $5.08 \mathrm{~cm}$, while when it is increased to $100 \mathrm{ppm}$; the height is also lower, at $1.41 \mathrm{~cm}$.

[18] claimed that the application of paclobutrazol up to $3000 \mathrm{mg}$ per liter on barley plant successfully reduce the plant' height. This statement is supported by a research by [2] on Zinnia plant which reported that the application of cycocel at $1.500 \mathrm{ppm}$ plants with lower height compared to the controlled ones.

\subsection{Effect of retardant on stem ring and bark thickness}

It can be clearly seen on Table 2 that the application of paclobutrazol is also able to decline the number of stem rings effectively, but it does not work well on bark thickness. The increase in the concentration of paclobutrazol from 500 to $1.250 \mathrm{ppm}$ lower the number of stem rings. On the concentration at $1.500 \mathrm{ppm}$, it is shown that the number of stem rings was on the lowest rate but it is not so much distinct from the concentrations at $1.250,1.000$, and $750 \mathrm{ppm}$. However, this result is not so much different from that of cycocel treatment, where the effect of same concentration treatments on cycocel is similar, but is different from the application of paclobutrazol at 1.250 and $1.500 \mathrm{ppm}$

This fact that the the number of of stem rings decreases when the concentration of paclobutrazol and cycocel increases can be obviously seen from the research finding. The increase in the number of stem rings is affected by the cambium activity because cambium is a meristem tissue that has an important role in the increase of organ's size. Cambium cell to divide due to stimulation by gibberellin. In the growing time, the inward cambium growth which is more active than the outward growth makes the stem's bark thinner than the woods.

\subsection{Effect of dormant apical shoot on easily peeled bark and the success of grafting}

Dormant condition is the inability to begin the growth of meristem under an advantageous condition. This inability, whether it is by cell extension or cell
Paclobutrazol dan cycocel contribute in suppressing gibberellin synthesis, so its content is decreasing. Because one of the functions of gibberellin is to stimulate pembelahan of cambium cells, so the decrease in gibberellin content will cause a decrease in the number of stem rings. [7] laimed that paclobutrazol not only retards shoot growth, but alsodecreases stem diameter growth and branches of woody plant. Cells extension on stem and leaves resulted from cambium is depending on gibberellin. Research by [4] found that application of paclobutrazol on soil can suppress the activity of cambium for four research seasons resulted in a decline in white and red oak's cambium total growth at $80 \%$ and $60 \%$ respectively.

\subsection{Effect of retardant on total leaves area and shoot dry weight}

Table 2 shows that the application of paclobutrazol and cycocel has little or no effect. However, data shows that the effect of treatment on both growth variables tends to show the same pattern, that the increase in the concentration of paclobutrazol and cycocelled to decreases in total leaves area and shoot dry weight. It is estimated that this relates to role of both retardants which can block gibberellin synthesis on terpenoid track, so the content decreases.

[7] claimed that the retardation effect of paclobutrazol on growth happens because it blocks gibberellin synthesis on terpenoid track : from entkaurene to entkaurenol and from ent-kaurenol to ent-kaurenal. Although gibberellin is retarded, the cells keep dividing but not expanding. The result is the growth reduction, but with the same number of leaves.

\subsection{Effect of retardant on easily peeled bark, carbohydrate, and the success of grafting}

Observation result of easily peeled bark, carbohydrate content, and the success of grafting in Table 3 shows that the treatment of paclobutrazol and cycocel is not effective. However, data shows that increasing concentration of paclobutrazol and cycocel tends to lower carbohydrate content on the bark of rubber seedling's rootstock. Based on this fact, it is estimated that gibberellin biosynthesis retardation by paclobutrazol and cycocel is still safe because it does not have adverse effects on such variables.

division, could happen due to the small number of organ or even the absence of organ [14].

Bud dormancy is a meristem buds that still has the ability to grow, but the process is slow growth. It is started with the leaves growth. Leaves which is supposed to grow well will be reduced to reduce into a 
kind of scales will cover tip of the shoot during dormant condition.

Table 3. Retardan influence on bark ripping, carbohidrat content dan grafting succes.

\begin{tabular}{|c|c|c|c|c|}
\hline \multirow{2}{*}{$\begin{array}{l}\text { Retardant } \\
(\mathrm{ppm})\end{array}$} & \multicolumn{4}{|c|}{ Variabel } \\
\hline & Bark ripping (\%) & $\begin{array}{c}\text { Carbohidrat content } \\
(\%)\end{array}$ & Grafting succes & $(\%)$ \\
\hline 0 & 90 & 7,70 & 93 & \\
\hline \multicolumn{5}{|l|}{ Paclobutrazol } \\
\hline 500 & 90 & 7,94 & 90 & \\
\hline 750 & 87 & 7,64 & 93 & \\
\hline 1.000 & 93 & 6,91 & 93 & \\
\hline 1.250 & 90 & 6,55 & 90 & \\
\hline 1.500 & 90 & 6,54 & 90 & \\
\hline \multicolumn{5}{|l|}{ Cycocel } \\
\hline 1.000 & 87 & 7,72 & 87 & \\
\hline 2.000 & 90 & 7,62 & 90 & \\
\hline 3.000 & 90 & 7,40 & 93 & \\
\hline
\end{tabular}

At the stage of scales formation, the cells which need energy obtained from food deposit will also reunite. This leads to the decrease in the energy and transportation of food deposit to another organ as sink such as stem. [9] explained that the division of assimilation product is generally transferred to the closest sink from source. Based on the explanation above, when the shoot is maintained, the limited food supply will reduce the supply to other part of the plant including the stem. This certainly will have an effect on the success of grafting.

\section{CONCLUSION}

Application of retardant can reduce dormant period of apical shoot without interfering with growth process of rubber seedling rootstock. The retardation of shoot growth reduces carbohydrate content in the skin of stem but it still can be easily peeled. The success of occulation still runs well because the ease in peeling rootstock's skin. Up to $1.000 \mathrm{ppm}$ dose of paclobutrazol as a retardant can be utilized as one of ways to slow shoot's dormant duration with relatively small interference with plant growth.

\section{ACKNOWLEDGMENTS}

Many thanks delivered to DIRJEN-DIKTI, Ministry of Research, Technology, and Higher Education that has given BPPS - Scholarship and all of the supporting teams that have helped in succeeding this research.

\section{REFERENCES}

[1] Amypalupy. K. 2014. Pembuatan Bahan Tanaman. Sapta Bina Usahatani Karet Rakyat (Editor; Sigit Ismawanto. Jamin Saputra. Lina Fatayati Syarifa dan Mili Purbaya). Hal. 23 -33. Balai Penelitian Sembawa-Pusat Penelitian Karet. Sumatera Selatan.

[2] Asgarian, H., A. Nabigol and M. Taheri. 2013. Effect of paclobutrazol and cycocel for height control of Zinnia. Intl. J. Agron. Plant Prod. 4 (S) : 3824 - 3827 .

[3] Daslin. Aidi. 2009. Teknisi Budidaya Tanaman Karet. Balai Penelitian Sungai Putih. Pusat Penelitian Karet. Medan

[4] Bai S., Chaney W., dan Yadong Q.. 2004. Response of cambial and shoot growth in trees treated with Paclobutrazol. Jurnal Arboriculture 30(3):137-145.

[5] Bora, R. K. and C. M. Sarma. 2006. Effect of gibeberellic acid and cycocel on growth yield and protein content of Pea. Asian Journal of Plant Science 5 (2) : $324-330$

[6] Campbell dan Reece JB.. 2012. Biologi. Edisi Kedelapan Jilid 2. Penerbit Erlangga. Jakarta. 441 hal.

[7] Chaney.W.R.. 2004. Paclobutrazol; More than just a growth retardant. Presented at Pro-Hort Conference. Peoria. Illinois. February 4th. 2004.

[8] Eristo. J. dan Budiyati. I.. 2014. Pertumbuhan Bibit Manggis (Garcinia mangostana L.) pada 
Berbagai Konsentrasi Cycocel di Media Tumbuh Ultisol. Prosiding Seminar Nasional Lahan Suboptimal 2014. Palembang 26-27 September 2014. 1 - 6

[9] Gardner F.P.. Pearce R.B.. Mitchell R.L.. Fisiologi Tanaman Budidaya. Penerbit UI-Press. 424 hal.

[10] Ghosh A.. Chikara J.. Chaudhary D.R.. 2010. Paclobutrazol arrests vegetative growth and unveils unexpressed yield potential of Jatropha curcas. J. Plant. Growth. Regul. DOI 10.1007/s00344-010

[11] Hadi. Rustan. 2010. Teknik dan Tingkat Keberhasilan Okulasi Beberapa Klon. Teknik Pertanian. 15(1) : 33-36

[12] Halle. F.. Oldeman. R.A.A.. and Tomlison. P.B.. 1978. Tropical Trees and Forests. Springer. Berlin.

[13] Kashid, D. A., M. B. Doddmani, M.B. Chetti, S. M. Hiremath and B.N. Arvindkumar. 2010. Effec of growth retardans on morpho-physiological traits and yield in sun flower. Karnataka J. Agric. Sci. 23 (2) : $347: 349$

[14] Rohde A. and Bhalerao R. P. 2007. Plant dormancy in the perennial context. T. In Plant Science. 12: $217-223$

[15] Runtunuwu. D.S. Mamarimbing R.. Tumewu P.. dan Sondakh T.. 2011. Konsentrasi Paclobutrazol dan pertumbuhan tinggi bibit Cengkeh (Syzygium aromaticum (L.) Merryl \& Perry). Eugenia 17:135-141

[16] Salisbury. F. B. dan C.W. Ross. 1995. Fisiologi tumbuhan. jilid 3 (Perkembangan tumbuhan dan fisiologi lingkungan). Penerbit ITB. Bandung

[17] Sarman, 2014. Studi Periode Dormansi dan Pertumbuhan Tunas Ujung Bibit Karet Batang Bawah Terhadap Keberhasilan Okulasi (bagian dari penelitian Disertasi). Tidak Dipublikasi

[18] Sharif. S., M. Saffari and Y. Emam. 2007. The effect of drought stress and cycocel on barley yield ( CV. Valfajr). J. Sci and Techol. Agric. and Nature Resour. vol. 10. no. 4(13.) Isf. Univ. Techol.. Techol. Isf.. Iran

[19] Simanjuntak. F. 2010. Teknis Okulasi Karet. Balai Besar Perbenihan dan Proteksi Tanaman Perkebunan Medan. Sumatera Utara. Artikel katagori IPTEK 2010.

[20] Winarno,F.G., (1977), Kimia Pangan dan Gizi, PT. Gramedia Pustaka Utama, hal.84-93, Jakarta. morpho-physiological traits and yield in sun flower. Karnataka J. Agric. Sci. 23 (2) : 347 : 349 